\title{
EMLÉKTÁBLAAVATÁS CHERNEL ISTVÁN BADACSONYI NYARALÓJA FALÁN
}

\author{
Faragó Sándor \\ Soproni Egyetem, Vadgazdálkodási és Gerinces Állattani Intézet \\ University of Sopron, Institute of Wildlife Management and Vertebrate Zoology \\ H-9400 Sopron, Bajcsy-Zs u. 4., Hungary
}

\begin{abstract}
FARAGÓ S. (2019): INAUGURATION OF ISTVÁN CHERNEL'S PLAQUE ON THE WALL OF HIS SUMMER COTTAGE IN BADACSONY. Hungarian Small Game Bulletin 14: 221-228. http://dx.doi.org/10.17243/mavk.2019.221

On $29^{\text {th }}$ October 2017 the local government of Badacsony (County Veszprém) raised a plaque to the memory of the Europe-famous researcher of Hungarian ornithology, who was the second leader of the Hungarian Ornithological Centre. The plaque was raised on the wall of the summer cottage of ISTVÁN CHERNEL at 83 Ibos Ferenc Street. Starting from this summer cottage ISTVÁN CHERNEL was inquiring into the avifauna of Badacsony and Lake Balaton between 1912 and 1922. After the dedication the celebrators were watching the program of the Himfy Literary Circle.
\end{abstract}

KULCSZAVAK: CHERNEL ISTVÁN, emléktábla, Badacsony

KEY WORDS: ISTVÁN CHERNEL, plaque, Badacsony

Badacsonytomaj város önkormányzata 2017. október 29-en emléktáblát állíttatott és avatott Badacsonytomaj Ibos Ferenc u. 83. sz. ház, CHERNEL IsTVÁN egykori nyaralóháza, falán.

Badacsonytomaj Város Önkormányzata és Kulturális Intézménye nevében BERECZ NiKOLETT, Badacsonytomaj Város Önkormányzat Kulturális Intézménye igazgatója köszöntötte az ünneplő egybegyülteket.

Minden ember azzal a szándékkal éli meg életét, hogy jelet, emléket hagyjon maga után. Az emberek többségének megadatik, hogy kisebb nagyobb alkotással élje túl halandó életét. Ma, ezen a borús őszi napon azért jöttünk össze, hogy chernelházi CHERNEL ISTVÁNRA emlékezzünk, tiszteletére emléktáblát avassunk. CHERNEL ISTVÁN 1865. május 27-én született Köszegen. Édesapja CHERnEl KÁlmÁN, édesanyja gróf tolnai FESTETICS MÁRIA volt. Édesapja elsősorban történész volt, de érdekelték a természettudományok is, főleg a madártan.

Badacsonytomaj Város Önkormányzat képviselö-testülete 83/2017. (III.01.) képviselö-testületi határozatával a „Szölö és Bor éve 2017" -hez kapcsolódóan - elfogadta Prof. Dr. FARAGÓ SÁNDOR, a Soproni Egyetem rektora javaslatát, hogy chernelházi CHERNEL ISTVÁN a magyar madártan Európa hírü kutatója emlékére emléktábla készüljön. Felkérte a javaslattevőt avatóbeszéde megtartására. A beszédet az utókor számára teljes terjedelmében közöljük.

Tisztelt Polgármester Úr, Tisztelt emlékezők, Hölgyeim és uraim!

A magyar tudományos madártan egyik legfényesebb csillagára, Európa-hírủ tudósára, a Magyar Ornithológiai Központ HERMAN OTTÓ utáni második igazgatójára, chernelházi CHERNEL ISTVÁNRA emlékezünk ma itt, a Badacsony oldalában, egykori villájánál. 
Megkülönböztetett tisztelettel köszöntöm KALTENEGGER ROZINSKY ÉVA asszonyt, a ház mai tulajdonosát, megköszönve Neki, hogy lehetővé tette az emléktábla elhelyezését. Ugyanilyen köszönet illeti Badacsonytomaj város önkormányzatát és személy szerint KRISZTIN N. LÁSZLÓ polgármester urat is, hogy az emléktábla elhelyezésével megörökítik a város egyik nagyhírü alakjának emlékét.

De $\mathrm{ki}$ is volt CHERNEL ISTVÁN? Ki volt az az ember, akinek emlékét a két éve, születésének 150 évfordulóján a Magyar Tudományos Akadémián, majd Kőszegen, tudományos ülésszakon méltattuk, Agárdon szobrot, Sopronban és most itt Badacsonyban emléktáblát kapott, illetve kap halálának 95 évfordulójára is emlékezve?

Százötvenkét esztendővel ezelőtt chernelházi CHERNEL KÁLMán és gróf FESTETICS MÁRIA gyermekeként született Köszegen. A nemesi családi háttér végigkísérte egész életét, befolyásolta világlátását, meghatározta kapcsolatait, amit ő önzetlenül hivatása szolgálatába állított.

Olyan családba született, amelynek tagjai sokat adtak a hazának, akik kitörölhetetlenül élnek a nemzet emlékezetében. Az ősök közül meg kell emlékeznünk FESTETICS IMRE grófról, CHERNEL ISTVÁN anyai ági dédapjáról, aki 1819-ben tette közzé téziseit „A természet genetikai törvényei" címen, csaknem fél évszázaddal megelőzve GREGOR MENDELt. Az ő testvére volt FESTETICS JÚLIA, a Nemzeti Múzeum és Országos Széchenyi Könyvtár alapító gróf SZÉCHENYI FERENCnek a felesége, akik pedig gróf SzÉCHENYI ISTVÁNnak, a legnagyobb magyarnak a szülei voltak. Ugyancsak testvére volt a dédapának a keszthelyi Georgikont alapító gróf FESTETICS GYÖRGY is. A mai értelembe vett tudományos munkát már CHERNEL KÁLMÁN, CHERNEL ISTVÁN édesapja is végzett, aki elsősorban a történettudományban és a muzeológiában alkotott máig hatóan maradandót. Az ő házasságával forrt össze a CHERNEL és FESTETICS család.

Nem túlzás azt állítani, hogy CHERNEL ISTVÁN életpályája a tudomány irányába, genetikailag eleve elrendeltetett volt.

\section{Tisztelt Emlékezök!}

A kis CHERnel ISTVÁn az elemi iskolát és a gimnázium alsó négy osztályát Kőszegen végezte, utóbbit a Bencés Gimnáziumban. Itt érték az első meghatározó élmények, mindenekelött FREH ALFONZ természetrajz tanárától. 1879-1883 között a Soproni Bencés Gimnáziumban tanult. Soproni tanárai közül FÁSZL IsTVÁNt (1838-1900) kell kiemelnünk, akinek hatására kiteljesedett madártani érdeklődése, $\mathrm{s}$ akitől a művészi színvonalú madárpreparálást is megtanulta. [FÁSZL ISTVÁN tanári hatását igazolja, hogy CSÖRGEY TITUSZ - aki CHERNELt követte a Madártani Intézet igazgatói székében - ugyancsak az Ö tanítványa volt Sopronban.]

Az érettségi után - akarata ellenére, de engedve az atyai nyomásnak - jogi tanulmányokat folytatott Pozsonyban, majd Budapesten. A koronázó városban, majd a fővárosban is a múzeumokat és könyvtárakat bújta. 1887-ben már megírta „A honi madártan történetéböl” címü első magyar ornitológiatörténetet, 1889-ben pedig a „Bibliographia ornithologica Hungarica" címü munkáját.

1887 öszén unokatestvére MESZLENY LAJOS megismertette HERMAN OTTÓval. HERMAN OTTÓ számára nem volt ismeretlen a CHERNEL név, hiszen CHERNEL ISTVÁN apjának, CHERNEL KÁLMÁNnak volt köszönhetö, hogy HERMAN OTTÓ e hazában maradt, s a természettudományok mellett más tudományterületek hazai polihisztor apostola vált belöle. HERMAN OTTÓ - aki 1863-1864-ben Köszegen tartott fenn fényképész mütermet - CHERNEL KÁLMÁN ajánlólevelével pályázott a kolozsvári Erdélyi Múzeum-Egylet konzervátori állására, $\mathrm{s}$ a jelentkezését BRASSAI SÁMUEL múzeumigazgató 1864-ben el is fogadta.

HERMAN OTTÓt a találkozás során meggyőzte a 22 esztendős CHERNEL IsTVÁN addigi tudományos teljesítménye, tudása, szakmai elkötelezettsége. 
Bár CHERNEL ISTVÁNT, miután 1888-ban befejezte jogi tanulmányait -herceg ESTERHÁZY PÁL, Sopron vármegye föispánja kinevezte közigazgatási gyakornoknak Sopronba, a HERMAN OTTÓ által megerősített hivatás csak 1889-ig tartotta a közigazgatásban.

1890 januárjától - HERMAN OTTÓ ajánlására - már a II. Nemzetközi Ornithológiai Kongresszus előkészítő bizottsága fötitkárává nevezték ki. CHERNEL IsTVÁN ekkor Budapestre költözött.

Még Modorban ismerte meg és jegyezte el pongyeloki ROTTH JÓzSEF és FRÖHLICH IRMA leányát ROTTH DORÁT, akit 1890. október 7-én feleségül vett. Sírig tartó mély és szép szerelem volt az övék, amely boldoggá, kiegyensúlyozottá tette CHERNEL ISTVÁN életét. Ide Badacsonyba is többnyire együtt érkeztek.

1891 májusában nagy szakmai és társadalmi siker mellett rendezték meg Budapesten a II. Nemzetközi Ornithológiai Kongresszust, egyszersmind megvalósult norvégiai utazása, amelyre CHERNEL IsTVÁNt elkísérte ifjú felesége is. Norvégiából Brüsszelen át Londonba, majd Párizsba vitt útjuk, ahol CHERNEL a múzeumok hatalmas madárbőr gyüjteményeit tanulmányozta.

Útjának mellékterméke volt a síelés meghonosítása Magyarországon, amit segítendő 1897-ben kiadta „A lábszánkózás kézikönyvét”.

A külföldi tanulmányutak tágították nemzetközi kapcsolatrendszerét, elmélyítették tudását a madártan minden területén.

Az európai körútról hazatérve, 1891 őszén CHERNEL ISTVÁn és RoTTH DORA véglegesen Kőszegen, a régi családi házban (CHERNEL-ház, korábban FESTETICS-ház) telepedett le, s ott élték le közös életük több mint 30 évét.

A II. Nemzetközi Ornithológiai Kongresszus tudomány-erjesztő hatása óriási változást, fejlődést eredményezett a magyar madártanban. Gróf CsÁKY ALBIN vallás és közoktatásügyi miniszter leiratban engedélyezte - HERMAN OTTÓ vezetésével - Magyar Ornithológiai Központ létesítését és személyzet alkalmazását. Az Ornithológiai Központ 1894-ben HERMAN OTTÓ szerkesztésében - már kiadta Aquila címü - máig élő - folyóiratának első kötetét, amelyben természetesen CHERNEL is több cikkel jelentkezett. CHERNEL IsTVÁN a Központ gyakorta bejáró külső munkatársává vált.

HERMAN OTTÓt ebben az időben három tehetséges fiatal tudós támogatta, GAAL GASZTON (1921-1922-ben a Nemzetgyülés elnöke), dr. ALMÁSY GYÖRGY (a későbbi híres Ázsia-kutató, ALMÁSY LÁSZló atyja) és CHERNEL IsTVÁN. HERMAN OTTÓ őket képzelte el a Központ állandó tisztikaraként. CHERNEL és ALMÁsY azonban nem szándékoztak sem Budapestre települni, sem kizárólag irodai munkát végezni.

1895-től indult meg CHERNEL IsTVÁN legmagasabb szintü tudományos karriere. 1898ban megjelent „Nomenclator avium Regni Hungariae” ami által megvetette a rendszeres magyar madártani nevezéktannak az alapjait.

1899-ben - 34 éves korában (!) - került ki a nyomdából kétkötetes fő müve, a „Magyarország madarai, különös tekintettel gazdasági jelentöségökre”, amely napjainkig a magyar leíró madártan legterjedelmesebb $(187+830=1017$ oldal), legteljesebb, meghatározó forrásgyüjteménye.

A könyv megjelenésével CHERNEL ISTVÁN itthon és külföldön a legelismertebb szaktekintélyek közé emelkedett. Ezzel egyidőben - Európa legkiválóbb ornitológusaival együtt - felkérték, hogy NAUMANN hatalmas német madárkönyve új kiadásának revíziójában vegyen részt.

Az új évszázad ismételten egy nagy vállalkozás megvalósulását hozta CHERNEL ISTVÁN számára. ALFRED BREHM „Az állatok világa - Tierleben” magyar nyelvü kiadásának három madár kötetét fordította le, $\mathrm{s}$ ahogy az alcímben is szerepel „Ismereteink mai színvonalához és a hazai viszonyokhoz alkalmazta Chernel István.” 1902-ben jelent meg a Magyar Brehm első kötete 694 oldal, 1903-ban a második kötete 678 oldal és 1904-ben a 
harmadik kötete 872 oldal terjedelemben. Ennek az összességében 2244 nyomtatott oldalnak (!) a megírása elképesztő munkabírásról tett tanúbizonyságot.

1900-ban Párizsban, 1905-ben Londonban, 1910-ben Berlinben képviselte Magyarországot a Nemzetközi Ornithológiai Kongresszusokon.

Az elismerések sem kerülték el CHERnEL ISTVÁNT! 1906-ban a Magyar Nyelvtudományi Társaság rendes tagjává választotta. 1908-ban elvállalta MÁDAY IzIDOR elnök mellett az Országos Állatvédő Egyesület alelnöki pozícióját is. A rákövetkező évben a Bajor Madártani Társaság tiszteletbeli tagjának választotta.

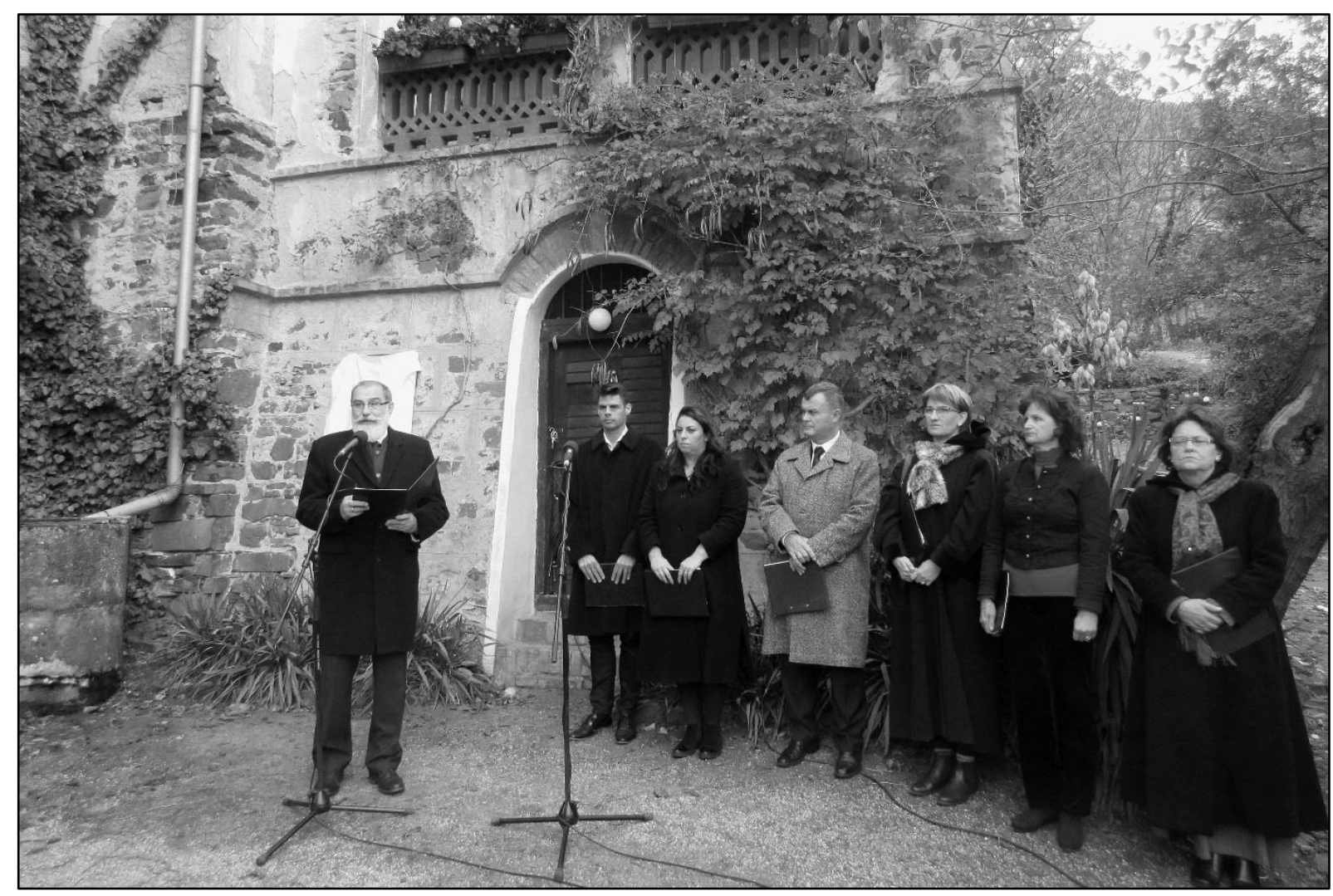

\section{1. ábra: FARAGó SÁNDOR avatóbeszédét mondja, mellette a Himfy Irodalmi Kör tagjai}

Figure 1: SÁNDOR FARAGÓ gives the opening speech; next to it is the Himfy Literary Circle

CHERNEL IsTVÁN igazi lokálpatrióta volt. A Szombathelyen létesített Vasvármegyei Múzeumban megalapította a Természetrajzi Osztályt, amelynek 1908-1912 között Ő volt első öre.

Emellett - elsősorban madártani és madárvédelmi tevékenységéért - több szervezet is tiszteleti titulussal ismerte el. Így lett a Soproni Állatvédő Egyesület tiszteletbeli elnöke (1901) a Pozsonyi Orvos-természettudományi Egyesületnek levelező tagja (1907). 1913-ban ismételten 3 évre megválasztották CHERNEL IsTVÁNt az Országos Állatvédö Egyesület és a Magyarországi Állatvédö Egyesületek Szövetsége alelnökévé.

HERMAN OTTÓ 1914. december végi halálával halaszthatatlan kérdésként merült fel első számú szellemi, szakmai és szervezeti örököse megnevezésének kérdése. Munkatársai az utódlásban egyértelmüen Chernel személyét támogatták, Ö azonban nem akart Budapestre költözni, s az alábbiakban gondolkodott: „Olyféle megoldás volna e tekintetben egyedül lehetséges, ha nem volnék kötve a fövároshoz, az adminisztrativ és gazdasági dolgok legföljebb csak felügyeletemre volnának bízva, ellenben az intézet tudományos irányítása, 
fejlesztése tartozna reám, az Aquila szerkesztése, gazdasági madártan körébe és a madárvédelembe vágó ügyek."

A miniszter számára sem volt szokványos a feltétel, de CHERNEL tekintélye, az intézet személyi állományának, mindenekelőtt CSÖRGEY TITUSZnak a véleménye egy év után meghozta a miniszteri kinevezést.

CHERNEL ISTVÁN 1922-ben bekövetkezett haláláig vezette a Madártani Intézetet - ezt a nevet is Ö adta neki - intenzív tudományos és tudományszervező tevékenységet folytatott. 1918-ban újra elkészítette „A Magyar Birodalom madarainak névjegyzéke” c. kötetet, amelyet az utókor igazgatói müködése alatt kiadott legjelentősebb müvének tekint. Szerkesztette az Aquilát amelynek 6 kötetét 2109 oldalon jegyezte, s amelyek nyomdai korrektúráit rendszeresen éppen itt Badacsonyban, e falak között végezte.

\section{Tisztelt Ünneplök!}

Ezzel az utolsó mondatommal el is érkeztem ahhoz a lehetöséghez, hogy összekössem e kiemelkedő, máig ható tudóst és Badacsonyt, illetőleg az Ibos Ferenc utca 83. házszám alatti házat.

A házat 1910. május 29-én bekövetkezett haláláig chernelházi CHERNEL GYULA Somogy megyei földbirtokos, országgyülési képviselő, főrendiházi tag tulajdonolta, aki CHERNEL ISTVÁNnak első unokatestvére volt (szüleik voltak testvérek). CHERNEL GYULÁnak nem voltak gyermekei, így a birtokait, beleértve a badacsonyi szőlőt és nyaralóházat CHERNEL ISTVÁN kiskorú gyermekére, CHERNEL MIKLÓSra hagyatékozta.

CHERnEl Gyula halálával az örökös CHERnEL MiKLós lett, aki felett a gyámságot CHERNEL ISTVÁN, az édesapa gyakorolta. Az öröklési rend természetesen viszályokhoz vezetett CHERNEL GYULA családja körében, amit 15 éves pereskedés követett, s csak CHERnEl Miklós hősi halála és CHERnEl IsTVÁN ugyancsak korai halála után, birtokmegosztással jutott nyugvópontra.

A kőszegi CHERNEL család a badacsonyi javakat 1912-ben vette birtokba, először CHERNEL IsTVÁN naplójából ismerjük - 1912. március 5-én jelent meg Badacsonyban. Abban az évben már 33 napot töltöttek itt, s az azt követő további 9, azaz összesen 10 évben CHERNEL ISTVÁN 1922-ben bekövetkezett haláláig - 41 alkalommal összesen 282 napot - 9,5 hónapot, évente eltérően 10 - 73 napot időztek e gyönyörü vidéken. A pihenés mellett a szőlőmüvelés és borászat is része volt a badacsonyi létnek, hiszen CHERNELéknek Kőszegen is volt szőlőbirtokuk és boruk is. 1919-ig KLUNG LAJOS, azt követően pedig KAJDI ISTVÁN volt a badacsonyi vincellérük. A bort részben CHERNEL GYULA özvegyének juttatta (a terméstől függően évi 5-10 hektót), főként azonban szombathelyi borkereskedők vették meg.

A háborús években és az az követő időszakban CHERNEL sokat panaszkodik a munkaerőhiányra, a drágaságra, a betegségekre és a piacra.

Badacsonyi tartózkodásának másik fontos vonulata volt az ornitológia. A Balaton, a Badacsonyi bazaltkúp mind-mind tartogattak ornitológiai érdekességeket, mint a kövirigó (itt a házban is fészkelt) és a szirti sas fészkelése, vagy a hajnalmadár és a havasi szürkebegy megjelenése. Innen járt át GAAL GASZTON-hoz a balatonboglári berekbe vadászni-madarászni is. Mindezekröl rövidebb-hosszabb cikkekben is beszámolt, az őszi madárvonulásról pedig évente.

A Badacsonyi estéket azonban társasági élettel töltötték a villatulajdonosok. A „szokásos társaság” - ahogy naplójában nevezte - zömében azonos osztálybeli, föként Vas vármegyei notabilitások köréből került ki. Kiemelkedő volt a második szomszéddal, BÉKÁSSY ISTVÁN főispánnal és családjával ápolt rokoni-baráti kapcsolat, de megemlítendő a BEZERÉDJ, a JEKElfalussy, a MALATINSZKY, a SZENTKIRÁlyi, a BOGYAY, az OKOLICSÁNYI, a báró SEEBACH, a SZEGEDY, a gróf ARZ-VASEGG és BERNRIEDER családokkal fenntartott barátság is. Helyi lakosok közül a FACKH családdal volt rendszeres a kapcsolat (távollétükben a 
pincekulcs is FACKHéknál volt), a család nagyasszonya FACKH GEDŐNÉ POELTENBERG ILONA, az aradi vértanú POELTENBERG ERNŐ tábornok leánya volt.

A közösen elköltött vacsorák, ebédek, borozgatások, éjszakába nyúló beszélgetések, éneklés-zenélés mind-mind az emberi kapcsolatokat mélyítette el. Tudni kell, hogy CHERNEL müvészi fokon citerázott, dalokat szerzett, amelyeket előadott vendégeinek, s kísérte az éneklést is. Itt Badacsonyban is külön citerái voltak e célra.

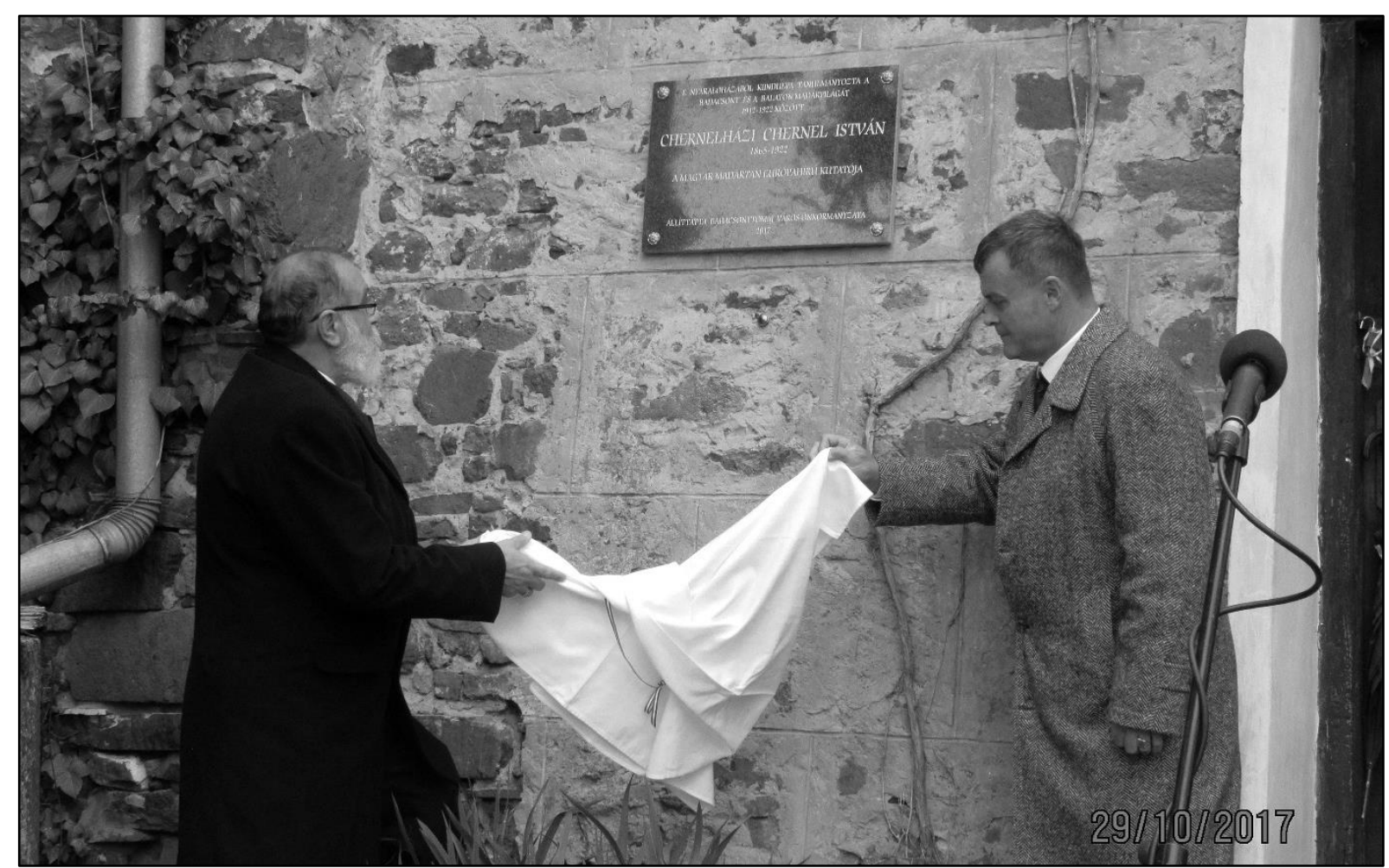

2. ábra: FARAGó SÁNDOR és KRISZTIN N. LÁSZLó leleplezi az emléktáblát

Figure 2: SÁNDOR FARAGÓ \& LÁSZLÓ KRISZTIN N. unveil the memorial

A hosszabb tartózkodások során CHERNEL leköltöztette Badacsonyba az egész háztartását, személyzettel együtt, s az Ötvöskónyi birtokról is hozatott alapanyagokat (húst, vadhúst) erre az időre. Így teremtődtek meg a badacsonyi alkotó és pihenőnapok, a társasági élet és a munka feltételei, amelyek CHERNEL munkáiban mind a felszínen, mind látensen megjelentek az itt eltöltött 10 év időszakában.

Tisztelt Hölgyeim és Uraim!

Ezen ismeretek és gondolatok jegyében kérem, hogy leplezzük le az emléktáblát, megköszönve mindazoknak, akik hozzájárultak felállításához! Hirdesse az utókornak egy kiváló tudósnak, egy kiváló magyar embernek itt, a Badacsony oldalában is megélt nagyszerüségét!

A jelen és a jövő a múltban gyökeredzik, ezért még különösebb gonddal kell őrködnünk annak megbecsülésén! - mondattal kérte fel BERECZ NIKOLETT KRISZTIN N. 


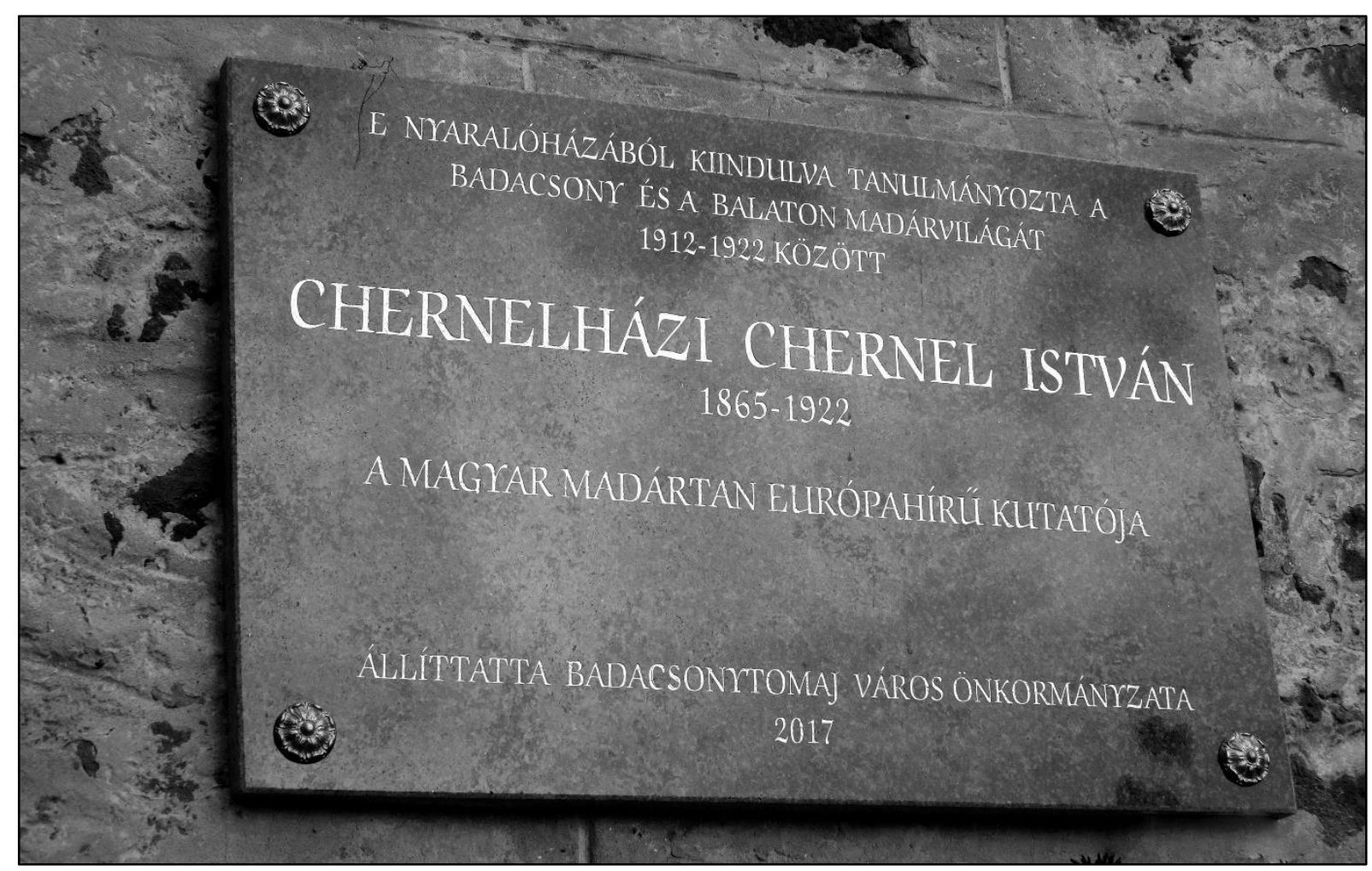

3. ábra: CHERNEL emléktábla Badacsonyban

Figure 3: CHERNEL's Plaque in Badacsony

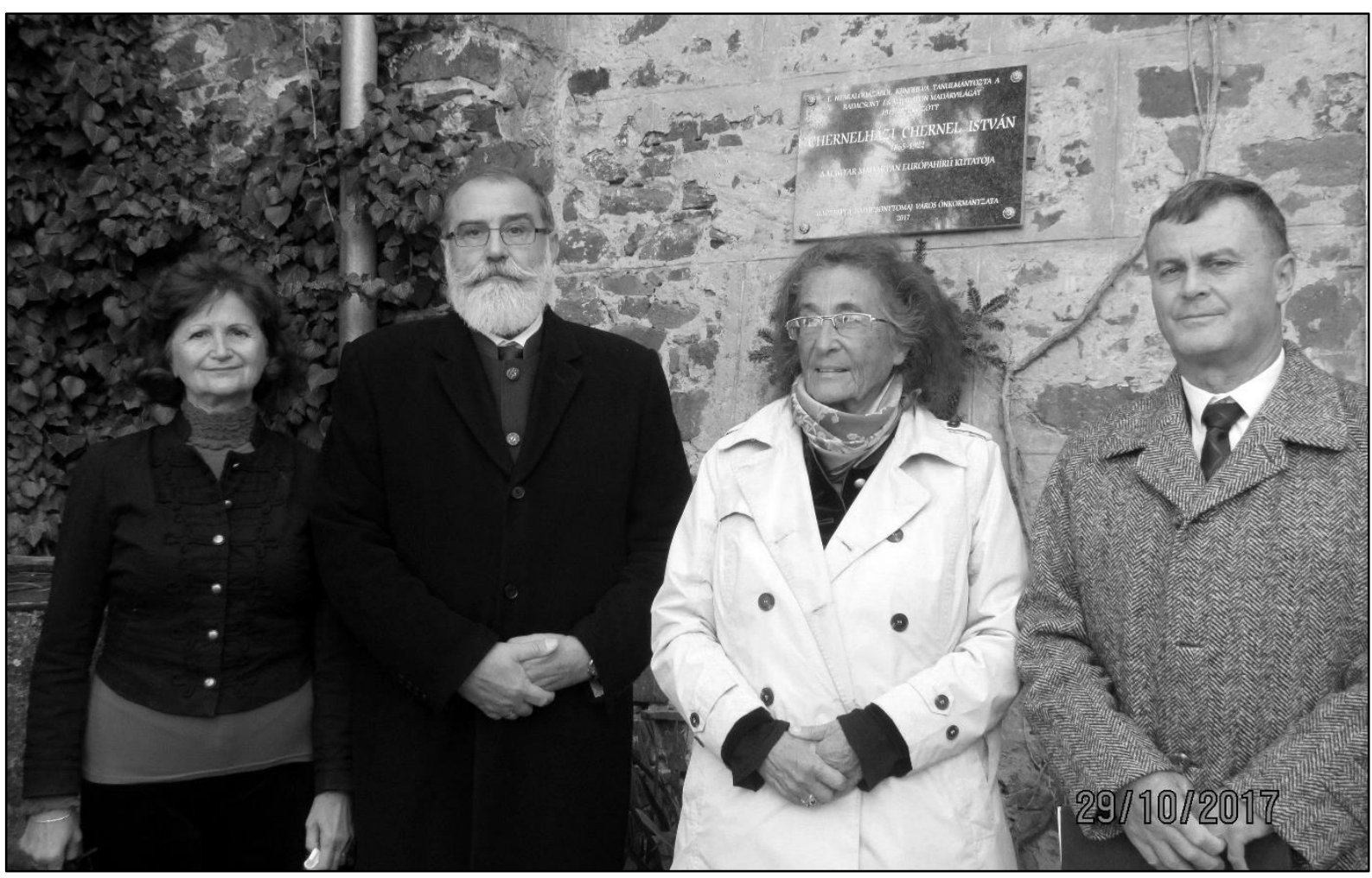

4. ábra: Az ünnepség kulcsszereplői: TóTH MARIANn, FARAGó SÁNDOR, KALTENEGgER ROZINSKY Éva és KRISZTIN N. LÁSZLÓ

Figure 4: Key persons of the ceremony: MARIANN TÓTH, SÁNDOR FARAGÓ, ÉVA KALTENEGGER ROZINSKY and LÁSZLÓ KRISZTIN N. 
LÁSZLÓT Badacsonytomaj város polgármesterét és Prof. Dr. FARAGÓ SÁNDORT a Soproni Egyetem rektorát, hogy leplezzék le az emléktáblát, majd ugyanők elhelyezték a megemlékezés koszorúit az emléktáblánál.

Az emléktábla avatást követően a Himfy Irodalmi Kör müsorát tekinthették meg az ünneplök, amelyet TÓTH MARIANN állított össze CHERNEL ISTVÁN ifjúkori verseiből. A verseket elmondták: Ali Éva, Tóth Mariann, SzÁntainé RuZSA MARIANN, KriszTin N. LÁSZLÓ és LAPOSA BENCE.

Az elhangzott CHERnEL versek az alábbiak voltak: Jelszavaim, Honvágy, Istenség, Élet, Tanács, Lélek, Törekvés, Munka, Tett, A magyar korona ünnepére, Hirnév, Áldozat, Arany János vesztesége, Lottihoz, Szerelem, A szerelem, V-nek I., V-nek II, Szerelmi dal, Réten, Virágzás, Tél és nyár, A természet alvása, Az erdőben, Óhaj, Természet, A tengerek, Tenger és szerelem, Kilátás (részlet), Szülöföldem (részlet).

\section{Kedves Emlékezők!}

Köszönet az őrzőknek, az emlékek őrzőinek, a táblaavatás ötletadóinak és megvalósítóinak, azoknak, akik felkarolták az emléktábla gondolatát. Emlékeztessen e márványtábla mindenkit a kiváló természettudós, előadó, vadász, síelő, zeneszerző. Fényképész, író, a madárvilág elmélyült kutatójára és védelmezőjére CHERNEL ISTVÁNRA, akinek egy 1901-ben leírt gondolata akár korunk ars poeticája is lehetne: „Fejlődjön és jusson belátásra az emberiségbolygónkon az önzetlenség, szeretet, béke és boldogság honoljon!" - zárta az ünnepséget BERECZ NIKOLETT.

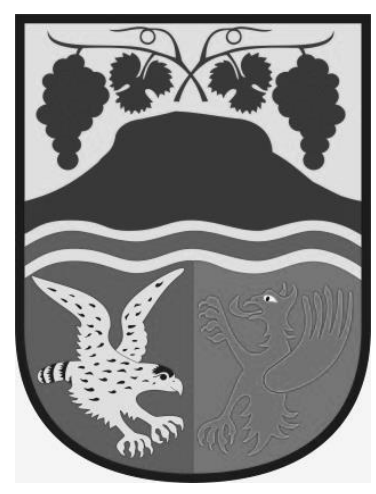

